\title{
Benign Non-Epithelial Gallbladder Neoplasm
}

National Cancer Institute

\section{Source}

National Cancer Institute. Benign Non-Epithelial Gallbladder Neoplasm. NCI Thesaurus.

Code C7129.

A non-metastasizing neoplasm arising from the gallbladder wall. The neoplastic process does not involve the epithelial layer. Representative examples include leiomyoma, lipoma, and neurofibroma. 